\title{
Konfirmasi Lima Faktor yang Berpengaruh terhadap Perilaku Remaja dalam Pencegahan HIV/AIDS
}

\author{
Ageng Septa Rini ${ }^{1}$, Ernita Prima Noviyani ${ }^{2}$ \\ 1,2 Program Studi Magister Kesehatan Masyarakat Sekolah Tinggi Ilmu Kesehatan Indonesia Maju \\ Jl. Harapan Nomor 50, Lenteng Agung-Jakarta Selatan 12610 \\ Telp: (021) 78894045, Email :1 septariniageng@yahoo.co.id, ${ }^{2}$ ernitaprima.stikim@gmail.com
}

\begin{abstract}
Abstrak
HIV adalah virus golongan RNA yang spesifik menyerang sistem kekebalan tubuh atau imunitas manusia dan menyebabkan AIDS/AIDS adalah sekumpulan dari gejala dan infeksi yang timbul karena rusaknya sistem kekebalan tubuh manusia akibat dari infeksi HIV. Tujuan penelitian mengetahui pengaruh peran tenaga kesehatan, sumber informasi, pola asuh orang tua, dan persepsi terhadap perilaku remaja di SMK Tunas Bangsa Kabupaten Tangerang Tahun 2018. Jenis penelitian ini adalah penelitian kuantitatif dengan desain penelitian cross sectional. Penelitian ini dilaksanakan pada bulan Februari 2018. Populasi dalam penelitian ini adalah seluruh remaja SMK Tunas Bangsa Kabupaten Tangerang. Metode analisis yang digunakan adalah Structural Equational Model (SEM) menggunakan Smart PLS 2.0 dan SPSS 18. Hasil penelitian menunjukkan variabel Perilaku Remaja dipengaruhi langsung peran tenaga kesehatan 9,543\%, sumber informasi $20,092 \%$, peran teman sebaya $32,563 \%$, pola asuh orag tua $9,043 \%$, dan persepsi $12,143 \%$. Sedangkan pengaruh peran tenaga kesehatan terhadap sumber informasi $9,888 \%$, peran tenaga kesehatan terhadap teman sebaya $2,123 \%$, peran tenaga kesehatan terhadap pola asuh orang tua $2,962 \%$, sumber informasi terhadap persepsi $4,282 \%$, peran teman sebaya terhadap pola asuh orang tua $6,910 \%$, peran teman sebaya terhadap persepsi $5,841 \%$, pola asuh orang tua terhadap persepsi $0,539 \%$. Dengan demikian ditarik kesimpulan bahwa peran teman sebaya yang paling mempengaruhi perilaku remaja, dikarenakan lingkungan keseharian disekolah lebih banyak dengan teman-temannya dalam bersosialisasi. Saran, orang tua dapat memberikan semangat dalam kegiatan yang diberikan atas prestasi anak remajanya dalam yang dapat berupa pemberian hadiah, penghargaan dan dijalinnya komunikasi yang baik antara anak remajanya dengan orang tua, terutama untuk anaknya dalam memilih teman dilingkungannya.
\end{abstract}

Kata kunci : HIV/AIDS, Peran Teman Sebaya

\begin{abstract}
HIV is a class of RNA virus that specifically attacks the immune system or human immunity and AIDS. AIDS is a collection of symptoms and infections that arise due to the destruction of the human immune system resulting from the infection of HIV.The purpose of this research is to know the influence of health manpower role, information source, parenting pattern, and perception toward adolescent behavior at SMK Tunas Bangsa Tangerang Regency Year 2018. This research type is quantitative research with cross sectional research design. The study was conducted in February 2018.The population in this study is all adolescents SMK Tunas Bangsa Tangerang District. The analysis method used is Structural Equational Model (SEM) using Smart PLS 2.0 and SPSS 18. The result of the research shows that the variable of adolescent behavior is directly influenced by the role of health manpower $9.543 \%$, information source $20.092 \%$, peer role $32.563 \%$, parenting $9.043 \%$, and perception $12.143 \%$. While the influence of health manpower to information source is $9.888 \%$, the role of health officer to peer $2.123 \%$, the role of health manpower to parenting parent $2.962 \%$, information source to perception $4.282 \%$, peer role to parenting pattern $6.910 \%$ peers against perception $5.841 \%$, parenting parent to perceptions $0.539 \%$. Thus drawn peer names that most affect adolescent behavior, get the daily environment in school more with friends in socializing. Suggestion, parents can give encouragement in activities given for their teenage achievements in the form of gifts, awards and good communication between adolescents and parents, especially for their children in choosing friends in their environment.
\end{abstract}

Keywords : HIV/AIDS, The Role of Peers 


\section{Pendahuluan}

HIV merupakan virus dari golongan RNA dimana spesifik menyerang sistem kekebalan tubuh atau imunitas manusia yang menyebabkan AIDS, sedangkan AIDS merupkan kumpulan suatu gejala dan infeksi yang timbul karena rusaknya sistem kekebalan tubuh manusia akibat dari infeksi HIV. ${ }^{(1)}(40)$

Masa inkubasi HIV 6 bulan sampai 5 tahun, Window period selama 6-8 minggu adalah keadaan dimana tubuh telah terinfeksi HIV dan belum bisa dideteksi olepemeriksaan laboratorium, seorang dengan HIV dapat bertahan sampai dengan 5 tahun, jika tidak diobati maka penyakit ini akan bermanifestasi sebagai AIDS. Gejala klinis muncul sebagai penyakit yang tidak khas seperti : Diare, Kandiasis mulut yang luas, Pneumonia interstisialis limfositik, Ensefalopati kronik. ${ }^{(2)}$

Gejala AIDS timbul 5-10 tahun setelah terinfeksi HIV. Beberapa orang tidak mengalami gejala saat terinfeksi pertama kali. Sementara yang lainnya mengalami gejala- gejala seperti flu, termasuk demam, kehilangan nafsu makan, berat badan turun, lemah serta pembengkakan saluran getah bening. (2)

Gejala yang dapat timbul oleh para penderita HIV/AIDS yaitu, tubuhnya menjadi lemah, sakit kepala, kehilangan memorinya, menggigil, rasa haus, nyeri pada sendi, depresi, tidak nafsu makan, panas tinggi, dan kelelahan. Berdasarkan dari data di Komisi Penanggulangan AIDS Nasional pada tahun 2015, dimana terjadinya angka kenaikan kasus HIV/AIDS yaitu terdapat sebesar 924.000 kasus, dimana didapatkan angka prevalensi $0,49 \%$. Angka ini mengalami kenaikan sangat pesat yaitu dimana didapatkan angka 2.117.000 kasus pada tahun 2025 atau terdapat nilai prevalensi 1,00\%12. Central Disease Control and Prevention (CDC) yang melaporkan kejadian HIV dimana terdapat di usia remaja yaitu 1324 tahun meningkat $22 \%$ dari Tahun 2010 . ${ }^{\text {(3) }}$
UNICEF menyatakan bahwa terjadinya trend yang sangat menghawatirkan karena terjadinya angka peningkatan dari jumlah kematian para remaja yang berusia 10- 19 tahun akibat HIV/AIDS di seluruh dunia yaitu 71.000 remaja pada tahun 2005 meningkat menjadi 110.000 jiwa pada tahun 2012. ${ }^{(4)}$

Tujuan ketiga dari Sustainable Development Goals (SDG's) yaitu menjamin kehidupan dengan sehat yang mensejahterakan untuk semua orang di segala usia yang terdapat 13 target dan salah satunya terdapat mengakhiri epidemi AIDS. ${ }^{(4)}$

Jumlah kumulatif infeksi HIV yang tercatat sampai bulan Desember 2016 yaitu 232.32. Jumlah kumulatif AIDS dari tahun 1987 sampai bulan Desember 2016 yaitu 86.780 orang. Persentase kumulatif AIDS tertinggi yaitu di umur 20-29 tahun (31,4\%), kemudian diikuti kelompok umur 30-39 tahun (30,6\%), 40-49 tahun (12,8\%), 5059 tahun $(4,5 \%)$ dan $15-19$ tahun $(2,7 \%)$. ${ }^{(5)}$

Penyakit HIV/AIDS dapat menular dengan berbagai cara, yaitu bisa melalui cairan tubuh contohnya darah, cairan genitalia, cairan sperma dan ASI. Virus juga terdapat pada air ludah, air mata dan urin tapi dengan konsentrasi yang sangat rendah. Obatobat anti retroviral dipakai untuk memperpanjang hidup manusia yag telah terkena infeksi. Obat-obat lain juga dipakai untuk melawan infeksi oportunistik yang dideritanya. Konsekuensi yang akan terjadi pada orang yang terinfeksi HIV hampir semua orang akhirnya akan menjadi AIDS dan meninggal karena komplikasi-komplikasi yang berhubungan dengan AIDS fisik maupun non fisik. ${ }^{(6)}$

Pencegahan HIV/AIDS dapat dilakukan melalui perubahan dari perilaku seseorang. Sebagian besar dari para ilmuwan sepakat bahwa untuk program pembagian jarum suntik secara gratis dan alat suntik, akan bisa mengurangi penggunaan jarum bergantian serta dapat mengurangi penyebaran infeksi melalui penggunaan narkoba intravera. Menggunakan jarum suntik yang tidak steril 
pada pengguna narkoba melalui suntik bisa dengan cepatnya menularkan infeksi HIV/AIDS kepada orang lain. Departemen Kesehatan mengatakan bahwa $75 \%$ orang penderita AIDS di Indonesia terinfeksi HIV yaitu terdapat pada usia remaja. Dengan demikian didapatkan bahwa fokus utama untuk mencegah penularan HIV/AIDS melalui hubungan seks yaitu (menghindari seks bebas), seseorang yang dapat menghilangkan kemungkinan tertular dengan melakukan hubungan monogami dengan hanya satu orang yang hasil tes HIV-nya negatif. $^{(7)}$

Pencegahan HV/AIDS bisa dilakukan dengan cara melakukan hubungan seks yang aman dan menghindari menggunakan jarum suntik hipodermik yang sudah di gunakan secara bersama-sama atau terkontaminasi. Upaya penanggulangan HIV/AIDS lewat jalur pendidikan mempunyai arti yang sangat strategis karena besarnya populasi remaja di jalur sekolah dan secara politis kelompok ini adalah aset dan penerus bangsa. Salah satu kelompok sasaran remaja yang paling mudah dijangkau adalah remaja di lingkungan sekolah (closed community). ${ }^{(6)}$

Upaya penanggulangan HIV/AIDS lewat jalur pendidikan memiliki makna yang begitu strategis dikarenakan besarnya populasi remaja di jalur sekolah hal mudah untuk dijangkau karena di lingkungan sekolah (closed community), media promosi kesehatan merupakan saluran (channel) untuk menyampaikan informasi kesehatan digunakan untuk mempermudah penerimaan pesan-pesan kesehatan. ${ }^{(8)}$

Gambaran perilaku siswa SMA untuk pencegahan HIV/AIDS di sekitar kota Kendari tahun 2016 adalah siswa yang mendapatkan berbagai jenis informasi dari upaya pencegahan HIV/AIDS yaitu sekitar 93,4\% siswa dan $6,6 \%$ siswa yang tidak mendapatkan informasi mengenai upaya pencegahan HIV/AIDS. Hasil analisis siswa SMA Negeri 1 Kendari mendapatkan 92,1\% siswa yang banyak mendapatkan informasi mengenai upaya pencegahan HIV/AIDS sedangkan $7,9 \%$ siswa tidak banyak mendapatkan informasi mengenai upaya pencegahan HIV/AIDS. Sebanding dengan siswa SMA Negeri 4 Kendari, dimana 94,3\% siswa telah banyak memperoleh informasi mengenai upaya pencegahan HIV/AIDS dan $5,7 \%$ siswa tidak banyak memperoleh sumber informasi dalam upaya pencegahan HIV/AIDS dan siswa SMA Negeri 5 Kendari memiliki $91,1 \%$ siswa yang telah banyak mendapatkan informasi mengenai upaya pencegahan HIV/AIDS dan 8,9\% siswa tidak banyak mendapatkan sumber informasi mengenai HIV/AIDS, siswa mendapatkan informasi dari orang tua, teman, guru, dan melalui media massa seperti televisi, dan internet sehingga memperoleh informasi. ${ }^{(9)}$

Faktor-faktor yang mempengaruhi perilaku pencegahan HIV/AIDS pada remaja , yaitu mengatakan bahwa nilai $p 0.019<\alpha$ 0.05 terdapat nilai korelasi 0.253 yang berpola positif yang menunjukkan bahwa sumber informasi mempunyai pengaruh yang signifikan terhadap perilaku pencegahan HIV/AIDS. ${ }^{(10)}$

Faktor-faktor yang mempengaruhi perilaku pencegahan HIV/AIDS pada remaja , yaitu mengatakan bahwa nilai $p 0.024<\alpha$ 0.05 dengan hasil korelasi 0.245 yang berpola positif hal ini menunjukkan bahwa teman sebaya berpengaruh yang signifikan terhadap perilaku pencegahan HIV/AIDS. ${ }^{(11)}$

Komisi Penanggualangan AIDS di Provinsi Banten dapat waspada pada peningkatan kasus HIV/AIDS, karena sesuai angka kasus capaian nasional dicatat pada akhir tahun 2016 yaitu melewati 300,000. Provinsi Banten pada tahun 2016 ini mengalami peningkatan mencapai 989 kasus. Bila jumlah infeksi HIV di Provinsi Banten pada 2014 mencapai 680 dan pada 2015 dilaporkan 649, maka pada tahun 2016 tercatat 989 kasus, presentasi meningkatnya di Provinsi Banten mencapai 52\% . Provinsi Banten masih masuk dalam 10 Provinsi pada kasus HIV terbanyak Tahun 2016 karena menempati posisi ke 8. Penyebaran infek HIV yang sangat cepat di Provinsi Banten perlu di tindak lanjut secara mendalam oleh semua pihak yang terkait. Remaja di Kabupaten 
Tangerang adalah kumpulan populasi penduduk yang mencapai $11,3 \%$ atau tepatnya mencapai 313.583 jiwa. Di usia $15-24$ tahun merupakan masa yang labil. Remaja adalah generasi suatu bangsa dengan segala permasalahannya sendiri. Korelasi pada situasi Kabupaten Tangerang sepanjang tahun 1998 sampai dengan oktober 2015 terdapat kasus HIV mencapai 617 orang, AIDS 327 orang, total keseluruhan 944 orang yang terinfeksi HIV/AIDS. Jumlah kasus sesuai umur, terhitung mulai januari sampai oktober 2015. Jika ada remaja yang tertular oleh HIV/AIDS adalah rata-rata usia 15-24 tahun mencapai 46 kasus, dimana angka remaja adalah penyumbang kasus urutan ke2, jadi ini berarti harus menjadi perhatian khusus di Kabupaten Tangerang. ${ }^{(12)}$

Disamping itu, dilakukan wawancara sementara oleh peneliti yang didapatkan melalui hasil prasurvey yang dilakukan di SMK Tunas Bangsa Kabupaten Tangerang, didapatkan informasi dari 20 orang siswa, 15 orang siswa mengetahui penyakit HIV/AIDS, tapi mereka tidak mengetahui bagaimana cara menularnya penyakit HIV/AIDS tersebut sedangkan 5 siswa lainnya tidak mengetahui penyakit HIV/AIDS.

\section{Metode}

Desain penelitian dilakukan dengan cara Cross-sectional (potong lintang) dimana menggunakan pendekatan kuantitatif. Penelitian ini dillaksanakan di SMK Tunas Bangsa Tangerang. Waktu penelitian adalah bulan Februari Tahun 2018.

Populasi dalam penelitian ini adalah seluruh siswa dari SMK Tunas Bangsa Kabupaten Tangerang dengan jumlah populasi 300 siswa. Jumlah sampel minimal adalah 5 dikali variabel bebas/indikator dan jumlah sampel maksimal adalah 10 dikali variabel bebas/indikator. Jumlah indikator dalam penelitian ini adalah 16 indikator, maka jumlah sampel minimal adalah 80 siswa remaja dan jumlah sampel maksimal adalah 160 siswa remaja. Jadi rentang (range) jumlah sampel yaitu siswa remaja, dalam hal ini peneliti mengambil 80-160 sebagai sampel. Jadi sampel penelitian ini mengambil jumlah maksimal yaitu 160 siswa remaja SMK Tunas Bangsa.
Peran dari tenaga kesehatan bisa dinilai dengan tiga indikator yaitu konselor, fasilitator dan edukator. Sumber informasi dapat diukur melalui tiga indikator reflektif yaitu media cetak, elektronik dan guru. Peran teman sebaya diukur dengan tiga indikator yaitu support, sosialisasi serta menjadi model atau contoh yang baik. Pola asuh orang tua diukur dengan indikator berdiskusi dengan anak, mengontrol anak dan memberikan penghargaan pada anak. Persepsi tidak memiliki indikator untuk diukur, sedangkan perilaku remaja dalam pencegahan HIV/AIDS diukur dengan tiga indikator yaitu mengikuti kelompok studi anti AIDS, menjauhi narkoba dan tidak melakukan hubungan seksual.

Kriteria inklusi adalah siswa SMK Tunas Bangsa Kabupaten Tangerang kelas X dan XI dan siswa yang bersedia untuk dijadikan sampel penelitian.

Kriteria eksklusi untuk sampel yaitu siswa yang tak hadir dan yang tidak bersedia untuk dijadikan sampel penelitian saat dilakukan pengumpulan data.

Analisis deskriptif yaitu analisis kuantitatif yang dipergunakan untuk menjelaskan lebih dalam lagi hasil dari analisis dan mampu memberikan informasi yang lebih rinci. Analisis deskriptif yaitu analisis kuantitatif yang digunakan dalam menjelaskan lebih mendalam lagi hasil dari analisis dan mampu memberikan informasi secara rinci. Analisis multivariat Structural Equation Modeling (SEM) dengan cara melihat discriminant validity dengan melihat nilai square root of average variance extracted (AVE). Nilai yang diinginkan adalah di atas 0,50 .

Pengolahan dari data output yang menggunakan bantuan SmartPLS 2.0 dimana disajikan dengan gambar, tabel dan lain-lain, ringkasan berupa tabel dari deskripsi yang utama.

\section{Hasil}

Responden dari penelitian ini umurnya paling banyak berusia 15 tahun, yaitu 53 orang $(33,1 \%)$, berdasarkan jenis kelamin memperlihatkan bahwa sebagian siswa berjenis kelamin laki-laki yaitu sebanyak 92 orang $(57,5 \%)$.

Berdasarkan gambar 1, didapatkan konstruk peran tenaga kesehatan diukur dengan tiga indikator yaitu konselor, fasilitator dan edukator. Sumber informasi diukur dengan tiga indikator reflektif yaitu media cetak, elektronik dan guru. Peran teman sebaya diukur dengan tiga indikator yaitu support,sosialisasi dan menjadi model atau 
contoh yang baik. Pola asuh orang tua diukur dengan indikator berdiskusi dengan anak, mengontrol anak dan memberikan penghargaan pada anak. Persepsi tidak memiliki indikator, sedangkan konstruk perilaku remaja dalam pencegahan HIV/AIDS diukur dengan tiga indikator yaitu mengikuti kelompok studi anti AIDS, menjauhi narkoba dan tidak melakukan hubungan seksual.

Berdasarkan gambar 1, dapat dilihat bahwa hasil loading faktor tertinggi yaitu pengaruh peran tenaga kesehatan ke pola asuh orang tua yaitu sebesar 0,833 dan hasil terendah yaitu pngaruh peran tenaga kesehatan ke persepsi yaitu sebesar 0,689 .

Pengaruh peran tenaga kesehatan keteman sebaya adalah sebesar 0,761 dan pengaruh peran tenaga kesehatan ke sumber informasi adalah sebesar 0,791. Nilai paling kecil yaitu sebesar 0,689 untuk indikator FS1. Berarti indikator yang digunakan dalam penelitian ini adalah valid dan sudah memenuhi convergent validity.
Pada hasil evaluasi AVE pada konstruk peran tenaga kesehatan yaitu 0,821 , perilaku remaja sebesar 0,838 , persepsi sebesar 1,000 , pola asuh orang tua sebesar 0,909 , sumber informasi sebesar 0,990 dan teman sebaya sebesar 0.887 , dikatakan valid apabila nilai AVE di atas 0,5 maka dapat disimpulkan bahwa evaluasi pengukuran model memilki discriminat validity yang baik, berarti semua indikator handal untuk mereflesikan variabelnya (nilai cronbach alpha> 0,70) baik.

Didapatkan bahwa hasil dari cronbach alpha yaitu dengan semua variabel berkisar 0.70 hingga 1,000 yang berarti semua indikator yang ada dalam mereflesikan variabelnya (nilai cronbach alpha> 0,70).

Pemeriksaan yang dilakukan selanjutnya yaitu pemeriksaan dari convergent validity adalah reliability yang merupakan konstruk dengan cara melihat dari output composite reliability atau cronbach's Alpha, dimana kriteria dalam penelitian ini akan dikatakan reliabel adalah jika hasil composite reliability atau cronbach's Alpha lebih dari 0,70 .

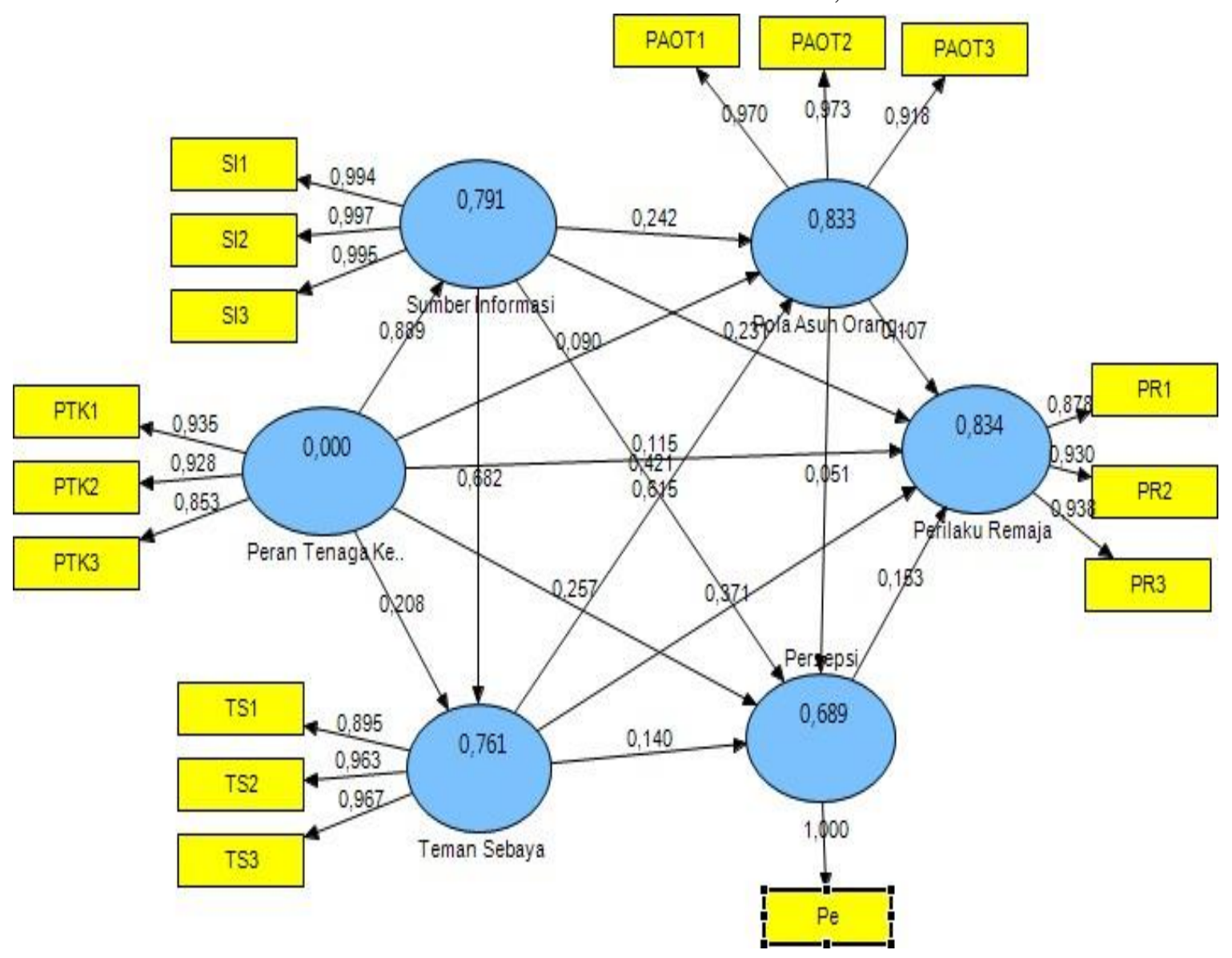

Gambar 1. Output PLS (Loading Factor) 


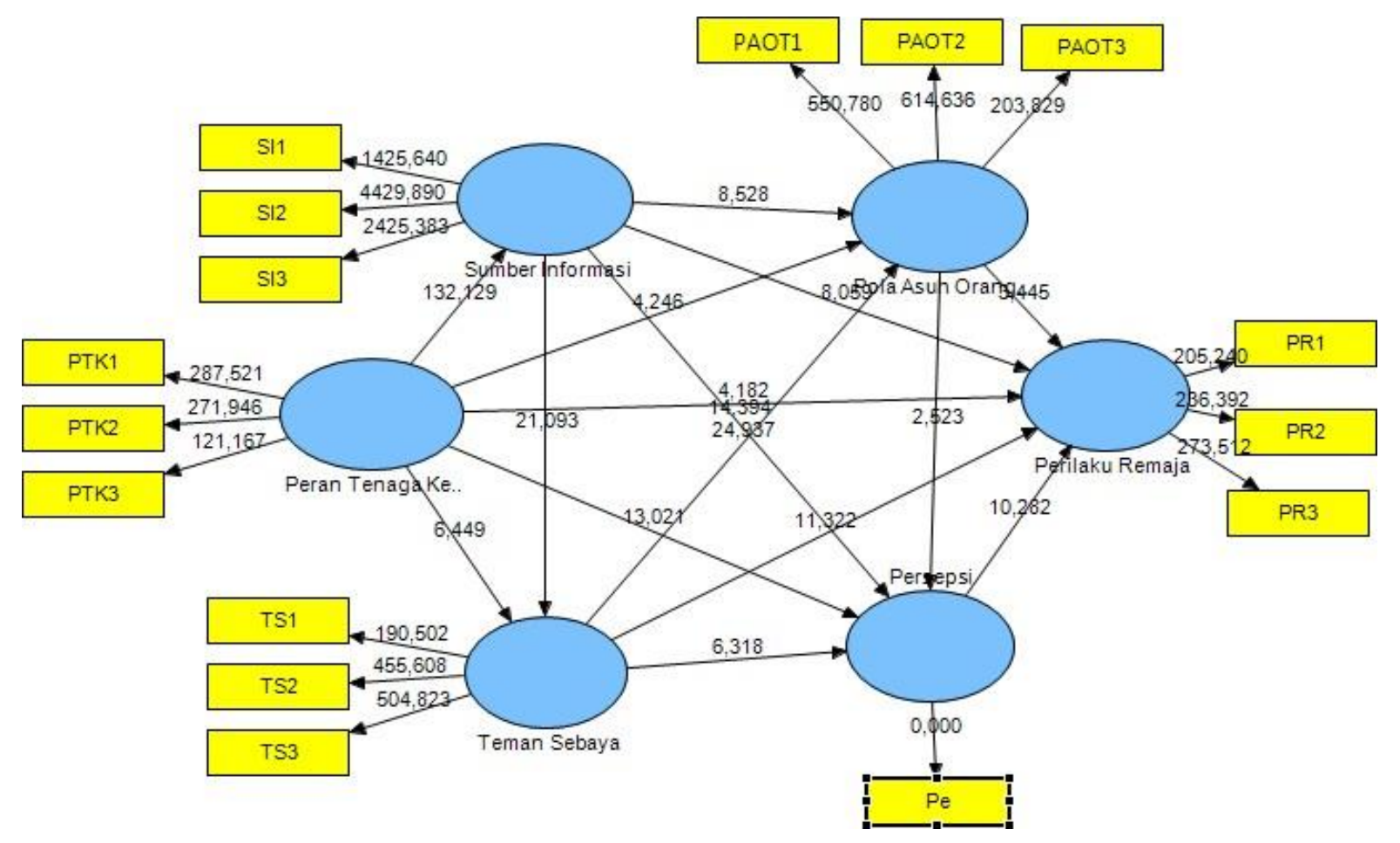

Gambar 2. Output uji T-Statistic

Berdasarkan gambar 2, terlihat bahwa menyatakan peran tenaga kesehatan berpengaruh positif terhadap sumber informasi, hasil ujinya menunjukkan ada pengaruh positif $(0,889389)$, sedangkan nilai T-Statistik sebesar $(132,129056)$ dan signifikan pada $\alpha=5 \%$, nilai $\mathrm{T}$-Statistik tersebut berada di atas nilai kritis $(1,96)$.

Peran tenaga kesehatan sangat berpengaruh positif terhadap teman sebaya yaitu sebesar $(0,814648)$, sedangkan nilai T-Statistik sebesar $(88,576546)$ dan signifikan pada $\alpha=5 \%$, nilai T-Statistik tersebut berada di atas nilai kritis $(1,96)$. Peran tenaga kesehatan berpengaruh positif terhadap pola asuh orang tua ada pengaruh positif sebesar $(0,806897)$, sedangkan nilai $\mathrm{T}$ Statistik sebesar $(72,822150)$ dan signifikan pada $\alpha=5 \%$, nilai T-Statistik tersebut berada di atas nilai kritis $(1,96)$. Peran tenaga kesehatan berpengaruh positif terhadap variabel persepsi, nilai menunjukkan ada pengaruh positif $(0,786250)$, sedangkan nilai T-Statistik sebesar $(114,889421)$ dan signifikan pada $\alpha=5 \%$, nilai $\mathrm{T}$ Statistik tersebut berada di atas nilai kritis $(1,96)$.
Peran tenaga kesehatan berpengaruh positif terhadap perilaku remaja ada pengaruh positif sebesar (0,829340), sedangkan nilai T-Statistik sebesar $(88,322415)$ dan signifikan pada $\alpha=5 \%$, nilai T-Statistik tersebut berada di atas nilai kritis $(1,96)$. Sumber informasi berpengaruh positif terhadap teman sebaya, ada pengaruh positif dengan nilai $(0,681552)$, sedangkan nilai $T$ Statistik sebesar $(21,093038)$ dan signifikan pada $\alpha=5 \%$, nilai T-Statistik berada di atas nilai kritis $(1,96)$. Sumber informasi berpengaruh positif terhadap pola asuh orang tua ada pengaruh positif yaitu (0,661486), sedangkan nilai T-Statistik sebesar $(19,343954)$ dan signifikan pada $\alpha=5 \%$, nilai T-Statistik tersebut berada di atas nilai kritis $(1,96)$. Sumber informasi berpengaruh positif terhadap persepsi, hasil uji menunjukkan ada pengaruh positif $(0,549409)$, sedangkan nilai $\mathrm{T}$ Statistik sebesar $(30,118771)$ dan signifikan pada $\alpha=5 \%$, nilai T-Statistik tersebut berada di atas nilai kritis $(1,96)$. Sumber informasi berpengaruh positif terhadap perilaku remaja, hasil uji menunjukkan ada pengaruh positif $(0,638554)$. 
Nilai T-Statistik sebesar $(18,851652)$ dan signifikan pada $\alpha=5 \%$, nilai $\mathrm{T}$-Statistik tersebut berada di atas nilai kritis $(1,96)$. Nilai dari berbagai macam uji hasil konstruk variabel dalam penilitian ini, maka didapatkan hasil penilaian yaitu konstruk Teman sebaya yang berpengaruh positif terhadap pola asuh orang tua yaitu sebesar $(0,615105)$, dan nilai T-Statistik sebesar $(24,936551)$ dan signifikan pada $\alpha=5 \%$, nilai $\mathrm{T}$ Statistik tersebut berada di atas nilai kritis $(1,96)$ dan berpengaruh positif terhadap persepsi, yaitu sebesar $(0,170719)$, sedangkan nilai T-Statistik sebesar $(9,164425)$ dan signifikan pada $\alpha=5 \%$, nilai T-Statistik tersebut berada di atas nilai kritis $(1,96)$, serta berpengaruh positif terhadap perilaku remaja yaitu sebesar $(0,463127)$, sedangkan nilai T-Statistik sebesar $(19,471654)$ dan signifikan pada $\alpha=5 \%$, nilai $\mathrm{T}$-Statistik tersebut berada di atas nilai kritis $(1,96)$.

Pola asuh orang tua berpengaruh positif terhadap persepsi yaitu sebesar $(0,050703)$, sedangkan nilai T- Statistik sebesar 2,523110 dan signifikan pada $\alpha=5 \%$, nilai T-Statistik tersebut berada di atas nilai kritis $(1,96)$ dan berpengaruh positif terhadap perilaku remaja yaitu sebesar (0,114813), sedangkan nilai T-Statistik sebesar 3,508912 dan signifikan pada $\alpha=5 \%$, nilai $\mathrm{T}$ Statistik tersebut berada di atas nilai kritis $(1,96)$.

Persepsi berpengaruh positif terhadap perilaku remaja, hasil uji menunjukkan ada pengaruh positif yaitu sebear $(0,153135)$, sedangkan nilai T- Statistik sebesar $(10,282106)$ dan signifikan pada $\alpha=5 \%$, nilai $\mathrm{T}$-Statistik tersebut berada di atas nilai kritis $(1,96)$.

Nilai $R$-Square digunakan dalam melakukan suatu penilaian, dimana penelitian ini menilai berapa besaran dari berbagai keragaman atau variasi dari data penelitian terhadap kejadian fenomena yang sedang dikaji. Kemudian selanjutnya akan dilakukan uji Inner Model yaitu pengujian terhadap model struktural yang dilakukan dengan melihat nilai $R$-Square yang merupakan uji goodness-fit model. Berikut ini adalah hasil pengukuran nilai $R$-Square, yang juga merupakan nilai goodness of fit model.
Tabel 1. Evaluasi Nilai $R$-Square

\begin{tabular}{lr}
\multicolumn{1}{c}{ Variabel } & \multicolumn{1}{c}{-Square } \\
\hline Peran Tenaga Kesehatan & \\
Perilaku Remaja & 0,833841 \\
Persepsi & 0,688674 \\
Pola asuh Orang Tua & 0,833056 \\
Sumber Informasi & 0,791013 \\
Teman Sebaya & 0,760729 \\
\hline
\end{tabular}

Berdasarkan tabel 1, nilai $R$-Square peran tenaga kesehatan berkontribusi terhadap sumber informasi sebesar $(0,791013)$, peran tenaga kesehatan, sumber informasi dan pola asuh orang tua berkontribusi terhadap teman sebaya sebesar $(0,760729)$, peran tenaga kesehatan dan sumber informasi berkontribusi terhadap pola asuh orang tua sebesar $(0,833056)$, peran tenaga kesehatan, sumber informasi dan teman sebaya berkontribusi terhadap persepsi sebesar $(0,688674)$, peran tenaga kesehatan, sumber informasi, teman sebaya, pola asuh orang tua dan persepsi berkontribusi terhadap perilaku remaja sebesar $(0,833841)$.

Berdasarkan pengukuran tersebut disimpulkan yaitu variabilitas peran tenaga kesehatan berkontribusi sumber informasi sebesar 79 sedangkan $21 \%$ dijelaskan oleh variabel lain yang tidak diteliti, peran tenaga kesehatan, sumber informasi dan pola asuh orang tua berkontribusi terhadap teman sebaya sebesar 76 sedangkan $24 \%$ dijelaskan oleh variabel lain yang tidak diteliti.Peran tenaga kesehatan dan sumber informasi berkontribusi terhadap pola asuh orang tua sebesar 83 sedangkan $17 \%$ dijelaskan oleh variabel lain yang tidak diteliti. Peran tenaga kesehatan, sumber informasi, teman sebaya berkontribusi terhadap persepsi sebesar 69 sedangkan $31 \%$ dijelaskan oleh variabel lain yang tidak diteliti, serta peran tenaga kesehatan, sumber informasi, teman sebaya, pola asuh orang tua, dan persepsi, berkontribusi terhadap perilaku remaja sebesar 83 sedangkan $17 \%$ dijelaskan oleh variabel yang tidak diteliti. Jadi, berdasarkan hasil penelitian diatas, hasil semua nilai $\mathrm{R}^{2}$ untuk variabel latent endogen adalah dengan hasil $\mathrm{R}^{2}$ lebih dari nilai 0.67 maka penelitian ini mengindasikan bahwa model "baik". 
Tabel 2. Persentase Pengaruh Langsung dan Tidak Langsung Pencegahan Perilaku Remaja

\begin{tabular}{|c|c|c|c|c|c|c|c|}
\hline Variabel & $\begin{array}{c}L V \\
\text { Correlation }\end{array}$ & $\begin{array}{l}\text { Direct } \\
\text { Rho }\end{array}$ & $\begin{array}{c}\text { Inderect } \\
\text { Rho }\end{array}$ & Total & $\begin{array}{c}\text { Direct } \\
(\%)\end{array}$ & $\begin{array}{c}\text { Inderect } \\
(\%)\end{array}$ & $\begin{array}{c}\text { Total } \\
(\%)\end{array}$ \\
\hline Peran Tenaga & 0,829 & 0,115 & 8,720 & 8,835 & 9,543 & 0,018 & 13,90 \\
\hline $\begin{array}{c}\text { Kesehatan } \\
\text { Sumber Informasi }\end{array}$ & 0,871 & 0,230 & 4,428 & 4,658 & 20,092 & 0,018 & 11,10 \\
\hline Teman Sebaya & 0,877 & 0,371 & 1,891 & 2,262 & 32,563 & 0,010 & 15,52 \\
\hline Pola Asuh & 0,844 & 0,107 & 0,589 & 0,696 & 9,043 & 0,005 & 20,58 \\
\hline \multirow[t]{2}{*}{ Persepsi } & 0,792 & 0,153 & - & 0,153 & 0,121 & - & 37,42 \\
\hline & & Total & & & 83,384 & 5,055 & 88,439 \\
\hline
\end{tabular}

Tabel 2 didapatkan bahwa peran tenaga kesehatan berpengaruh secara langsung dan tidak langsung terhadap perilaku. Hasil uji koefisien parameter antara peran tenaga kesehatan terhadap perilaku didapatkan pengaruh langsung sebesar $9,543 \%$, sedangkan untuk pengaruh tidak langsung antara peran tenaga kesehatan terhadap perilaku melalui sumber informasi, teman sebaya, pola asuh orang tua maupun persepsi didapatkan nilai sebesar 0,810\%. Sumber Informasi berpengaruh secara langsung dan tidak langsung terhadap perilaku. Hasil uji koefisien parameter antara sumber informasi terhadap perilaku didapatkan pengaruh langsung sebesar 20,092\% dan pengaruh tidak langsung antara variabel sumber informasi terhadap perilaku melalui teman sebaya, pola asuh orang tua, persepsi didapatkan nilai sebesar $0,018 \%$.

Teman Sebaya berpengaruh secara langsung dan tidak langsung terhadap perilaku. Hasil uji koefisien parameter antara teman sebaya terhadap perilaku didapatkan pengaruh langsung sebesar $32,563 \%$, dan untuk pengaruh tidak langsung antara sumber informasi, pola asuh orang tua dan persepsi didapat nilai sebesar $0,010 \%$.

Pola Asuh Orang Tua berpengaruh secara langsung dan tidak langsung terhadap perilaku, hasil uji koefisien parameter antara Pola Asuh Orang Tua terhadap Perilaku didapatkan hasil pengaruh langsung sebesar $9,043 \%$ sedangkan hasil untuk pengaruh yang tidak langsung antara pola asuh orang tua, persepsi terhadap perilaku didapatkan dengan didapat nilai sebesar $0,005 \%$. Maka semua konstruk diatas memiliki nilai pengaruh langsung dan tidak langsung.
Persepsi berpengaruh secara langsung terhadapperilaku. Hasil uji koefisien parameter antara persepsi terhadapperilaku didapatkan pengaruh langsung sebesar $0,121 \%$. Sehingga nilaidari masing-masing pengaruh langsung variabel laten independen tersebut apabila secara bersama-sama menunjukkan kesesuaian dengan nilai $\quad R$ Square atau dengan kata lain hal ini menyatakan bahwa variabel peran tenaga kesehatan, sumber informasi, teman sebaya, pola asuh orang tua, dan persepsi mampu menjelaskan variabel perilaku sebesar

$$
\begin{aligned}
& 9,543 \%+12,14 \%+32,563 \%+9,043 \%+ \\
& 0,121 \%)=83,384 \% .
\end{aligned}
$$

Sedangkan pengaruh tidak langsung dari variabel peran tenaga kesehatan, sumber informasi,teman sebaya, pola asuh orang tua terhadap variabel perilaku sebesar $(0,810 \%+0,810 \%+0,010 \%+$ $0,005 \%)=5,055 \%$. Jadi total pengaruh langsung dan tidak langsung sebesar $88,439 \%$.

\section{Pembahasan}

\section{Pengaruh Peran Tenaga Kesehatan terhadap Perilaku Remaja dalam Pencegahan HIV/AIDS}

Hasil pengujian peran tenaga kesehatan terhadap perilaku terdapat nilai $\mathrm{T}$ statistik sebesar $132,129056>1,96$. Dengan didapatkan hasil penelitian ini adanya pengaruh peran tenaga kesehatan terhadap perilaku. Sehingga parameter tenaga kesehatan terhadap perilaku didapatkan nilai signifikan.

Perilaku merupakan segala kegiatan dan aktifitas yang dikerjakan oleh manusia yang bisa diamati langsung maupun yang tidak langsung atau tidak bisa diamati oleh pihak luar. ${ }^{(13)}$ 
Perilaku seksual beresiko akan meningkatkan kemungkinan seseorang terinfeksi HIV/AIDS. Pencegahan HIV/AIDS dapat terjadi melalui perilaku yang berubah. Para ilmuwan berpendapat bahwa sepakat dalam programprogram menggantikan jarum suntik atau membagikan jarum suntik secara gratis dan alat suntik, mengurangi kegunaan jarum secara bergantian dan mengurangi penyebaran infeksi lewati penggunaan intravera. ${ }^{(6)}$

Perilaku seseorang dipengaruhi oleh tiga faktor penting, yaitu : Pertama, faktor predisposisi meliputi sikap, keyakinan, nilai- nilai dan persepsi dimana berhubungan dengan motivasi seserang atau kelompok untuk melakukan tindakan. Selain itu, status sosial ekonomi, umur, jenis kelamin dan jenis keluarga saat ini juga merupakan cakupan dari faktor predisposisi. Kedua, Faktor pemungkin merupakan faktor antesenden terhadap perilaku yang memungkinkan motivasi atau aspirasi terlaksana. Hal yang termasuk dalam faktor ini adalah kemampuan dan sumber daya yang dibutuhkan untuk melakukan suatu perilaku kesehatan. dan ketiga faktor penguat merupakan faktor yang ada setelah perilaku dilakukan. Faktor ini dapat berupa nilai positif maupun negatif dipengaruhi oleh sikap dan perilaku orang-orang yang berkaitan. Hal yang termasuk dalam faktor ini adalah manfaat sosial, manfaat fisik, serta ganjaran nyata atau tidak nyata yang pernah diterima oleh seseorang. Sumber faktor penguat ini dapat berasal dari tenaga kesehatan, kawan dan keluarga. ${ }^{(13)}$

Hal ini juga sejalan dengan penelitian dimana hasil tabulasi silang menunjukan bahwa proporsi responden yang tidak baik dalam perilaku pencegahan lebih banyak terdapat pada kelompok yang dukungan tenaga kesehatan kurang dukungan $(83,3 \%)$ dibandingkan dengan kelompok yang dukungan tenaga kesehatan mendukung $(26,2 \%)$. Hasil uji chi square didapatkan hasil $\mathrm{p}=0,000$ dimana $\mathrm{p}<0,05$, Ho ditolak sehingga ada hubungan yang bermakna dukungan tenaga kesehatan dengan perilaku pencegahan penularan HIV/AIDS. ${ }^{(14)}$

Berdasarkan pembahasan di atas maka penulis berpendapat bahwa semakin baik peran tenaga kesehatan memberikan pendidikan kesehatan maka yang didapatkan oleh remaja tentang perilaku pencegahan HIV/AIDS lebih baik, maka semakin baik pula perilaku remaja terhadap pencegahan HIV/AIDS tersebut. Untuk meningkatkan perilaku remaja agar lebih baik dapat dilakukan dengan cara memberikan konselor, fasilitator dan edukator. diinformasikan setiap kelas untuk mendapatkan ilmu yang berguna bagi remaja.

\section{Pengaruh Sumber Informasi terhadap Perilaku Remaja dalam Pencegahan HIV/AIDS}

Hasil sumber informasi terhadap perilaku didapat dengan nilai $\mathrm{T}$ statistik sebesar 18,851652 $>1,96$, hasil penelitian ini ada pengaruh sumber informasi terhadap perilaku. Sehingga parameter sumber informasi terhadap perilaku dikatakan signifikan.

Perilaku seseorang dipengaruhi oleh tiga faktor penting, yaitu : Pertama, faktor predisposisi meliputi sikap, keyakinan, nilai- nilai dan persepsi yang berhubungan dengan motivasi individu atau kelompok untuk melakukan tindakan. Selain itu, status sosial ekonomi, umur, jenis kelamin dan jenis keluarga saat ini juga merupakan cakupan dari faktor predisposisi. Kedua, Faktor pemungkin yaitu faktor antesenden trhadap perilaku yang memberikan motivasi agar menjaidi lebih baik. Hal yang termasuk faktor ini adalah kemampuan dan sumber daya yang dibutuhkan untuk melakukan suatu perilaku kesehatan. Dan ketiga faktor penguat merupakan faktor yang ada setelah perilaku dilakukan. Faktor ini dapat berupa nilai positif maupun negatif dipengaruhi oleh sikap dan perilaku orang-orang yang berkaitan. ${ }^{(15)}$

Hal yang termasuk dalam faktor ini yaitu manfaat sosial, fisik, serta ganjaran nyata atau tidak nyata yang pastinya pernah diterima oleh setiap individu. Sumber faktor penguat ini dapat berasal dari tenaga kesehatan, teman dan keluarga. ${ }^{(15)}$

Informasi dapat di artikan sebagai segala sesuatu yang bisa memberikan tambahan pengetahuan dan wawasan kepada seseorang atau banyak orang, untuk mendapatkan suatu kebenaran yang ingin dicarinya dalam suatu informasi. ${ }^{(16)}$

Sumber informasi merupakan segala informasi yang diperoleh seseorang untuk mendapatkan apa yang dia cari dan didapatkan dari segala arah. Media promosi kesehatan yaitu saluran (channel) untuk menyampaikan informasi kesehatan. $^{(17)}$ 
Hal ini sejalan dengan penelitian hasil uji statistik menggunakan uji Chi Square diperoleh hasil $p$ value $=0,000<\alpha=0,05$ dan Ho ditolak yang artinya ada hubungan antara sumber informasi dengan upaya pencegahan HIV/AIDS pada remaja komunitas anak jalanan di Banjarmasin Tahun 2016. ${ }^{(18)}$

Berdasarkan dari pembahasan di atas maka penulis berpendapat bahwa semakin banyak sumber informasi yang didapatkan oleh remaja tentang perilaku pencegahan HIV/AIDS, maka semakin baik pula perilaku remaja terhadap pencegahan HIV/AIDS tersebut. Untuk meningkatkan perilaku remaja agar lebih baik dapat dilakukan dengan cara penyuluhan, konseling, melalui media cetak, media lain seperti leaflet diberikan setiap kelas untuk memperoleh ilmu yang berguna bagi remaja.

\section{Pengaruh Teman Sebaya terhadap Perilaku Remaja dalam Pencegahan HIV/AIDS}

Hasil pengujian teman sebaya terhadap perilaku didapat dengan nilai $\mathrm{T}$ statistik sebesar $19,471654>1,96$. Dengan demikian hasil penelitian ini ada pengaruh teman sebaya terhadap perilaku. Sehingga parameter teman sebaya terhadap perilaku dikatakan signifikan.

Teman sebaya merupakan kelompok remaja yang mereka nilai menganut oleh remaja lain yaitu yang berfungsi sebagai tempat untuk berbagi dan sharing perubahan perilaku remaja dan juga merupakan sebagai kelompok acuan untuk saling curhat antara satu sama yang lainnya, dengan lingkungan social diskelilingnya yang dimana ia beranjak dari tempat tinggalnya, dimana remaja tersebut menyerap beberapa norma yang ada dan nilai-nilai lingkungan tempat tinggalnya yang akhirnya menjadi standar nilai yang mempengaruhi pribadi remaja dengan tingkat usia yang sama. ${ }^{(19)}$

Hal ini sama dengan penelitian uji analisa bivariat antara variabel perilaku teman sebaya dimana perilaku seksual berisiko HIV/AIDS dan IMS didapatkan hasil yang menunjukkan bahwa adanya hubungan yang signifikan antara perilaku teman sebaya dengan perilaku seksual berisiko HIV/AIDS dan IMS ( $p$ value $=0,044)$, jadi didapatkan nilai dari hasil penelitian ini yang bisa mendukung hipotesis yang telah diterapkan di dalam penelitian ini. ${ }^{(11)}$

Berdasarkan pembahasan di atas maka penulis berpendapat bahwa semakin sering teman sebaya memberikan dukungan kepada 147 sesama sebaya dengan dukungan yang baik yang didapatkan oleh remaja tentang perilaku pencegahan HIV/AIDS, maka semakin baik pula perilaku remaja untuk pencegahan HIV/AIDS tersebut.

\section{Pengaruh Pola Asuh Orang Tua terhadap Perilaku Remaja dalam Pencegahan HIV/AIDS}

Hasil pengujian pola asuh orang tua terhadap perilaku didapat hasil nilai $\mathrm{T}$ statistik sebesar 3,508912 > 1,96. Dimana hasil dari penelitian ini ada pengaruh pola asuh orang tua terhadap perilaku. Sehingga parameter pola asuh orang tua terhadap perilaku dikatakan signifikan.

Pola pengasuhan yaitu system atau cara yang diterapkan orang tua di kehidupan seharihari kepada anak, dengan cara mengasuh, membina, menesehati, membimbing, dan memimpin anak. Pola asuh adalah sikap orang tua dalam berkomunikasi, membimbing, dan mendidik anak-anaknya dalam kehidupan sehari-hari. $^{(20)}$

Hal ini sejalan dengan penelitian yang uji hasil pola asuh orang tua menunjukkan bahwa $98,9 \%$ responden memiliki orang tua dengan pola asuh autoritatif (demokratis). Sementara sisanya memiliki orang tua dengan pola asuh otoriter dan tidak seorangpun dari responden yang memiliki orang tua dengan pola asuh permisif. $^{(21)}$

Berdasarkan pembahasan di atas maka penulis berpendapat bahwa semakin baik asuhan orang tua yang didapatkan oleh remaja tentang perilaku pencegahan HIV/AIDS, maka perilaku remaja terhadap pencegahan HIV/AIDS tersebut semakin baik juga, setiap kelas dalam pendidikan dapat memberikan informasi untuk memperoleh ilmu yang berguna untuk remaja.

\section{Pengaruh Persepsi terhadap Perilaku Remaja dalam Pencegahan HIV/AIDS}

Hasil pengujian persepsi terhadap perilaku didapat nilai $\mathrm{T}$ statistik sebesar 10,282106 > 1,96, dimana hasil penelitian ini ada pengaruh persepsi terhadap perilaku, sehingga parameter persepsi terhadap perilaku dikatakan signifikan.

Persepsi merupakan suatu pengetahuan yang mengenali objek atau kejadian sekitar dengan bantuan indera, secara umum persepsi juga sebagai variabel yang mempengaruhi faktor-faktor perangsang, seperti ingin belajar, 
keadaan psikis, keadaan hati dan faktor-faktor motivasional, maka arti suatu objek atau suatu kejadian objektif ditentukan oleh kondisi perangsang dan faktor orgasme, sehingga persepsi antara seorang dengan orang yang lainnya berbeda-beda karena mengalami situasi yang berbeda. ${ }^{(22)}$

Hal ini sejalan dengan analisis hubungan antara persepsi kerentanan dengan perilaku pencegahan penularan HIV/AIDS di Kabupaten Kudus tahun 2015 didapatkan bahwa dari 7 responden yang persepsi kerentanan kurang baik perilaku pencegahan yang tidak baik, dan dari 1 responden yang memiliki persepsi kerentanan baik memiliki perilaku pencegahan yang tidak baik. Sedangkan dari 15 responden yang memiliki persepsi kerentanan kurang baik memiliki perilaku pencegahan yang baik, dan dari 19 responden yang memiliki persepsi kerentanan baik memiliki perilaku pencegahan yang baik pula. Hasil analisis $\mathrm{p}=0,069(>0,05)$ jadi Ho diterima. ${ }^{(23)}$

Peran tenaga kesehatan sesuai dengan pekerjaannya yaitu sebagai tenaga medis, dan tenaga paramedis seperti keperawatan, tenaga kebidanan, tenaga penunjang medis dan lain sebagainya dimana sebagai sistem informasi yang merupakan dari berbagai macam komponen-komponen yang saling berkaitan yang bekerja bersama-sama untuk mengumpul kan, mengolah, menyimpan, dan menampilkan informasi untuk mendukung pengambilan keputusan, koordinasi, pengaturan, analisa, dan visualisasi pada sebuah organisasi. ${ }^{(24)}$

Peran adalah suatu tindakan yang bermanfaat untuk memahami suatu interaksi antara individu sebagai pelaku (actors) yang dijalankan berbagai macam peranan di dalam hidupnya, seperti dokter, perawat, bidan dan petugas kesehatan lain yang mempunyai tanggung jawab menjalankan tugasnya atau kegiatannya yang sesuai dengan peranannya masing - masing. ${ }^{(25)}$

Hal ini sejalan dengan penelitian hubungan antara peran petugas kesehatan dan sumber informasi dengan prilaku seksual di daerah Mergangsang Yogyakarta. Keeratan hubungan menunjukkan kategori rendah berdasakan nilai koefisien kontigensi sebesar 0,284 dan 0,305 berada pada interval 0,20 $0,399 .{ }^{(26)}$
Berdasarkan pembahasan di atas maka Penulis berpendapat bahwa persepsi seorang remaja tentang perilaku pencegahan HIV/AIDS, jika persepsi baik maka perilaku remaja terhadap pencegahan HIV/AIDS tersebut akan baik.

\section{Pengaruh Peran Tenaga Kesehatan terhadap Sumber Informasi dalam Pencegahan HIV/AIDS}

Hasil pengujian peran tenaga kesehatan terhadap sumber informasi didapat dengan nilai $\mathrm{T}$ statistik sebesar 132,129056 > 1,96. Dengan demikian hasil penelitian ini ada pengaruh peran tenaga kesehatan terhadap sumber informasi. Sehingga peran tenaga kesehatan parameter terhadap sumber informasi dikatakan signifikan.

Petugas kesehatan merupakan seseorang yang memberikan pelayanan kesehatan kepada individu ataupun keluarga dalam masyarakat kesehatan dan sumber informasi yang didapatkan oleh remaja tentang perilaku pencegahan HIV/AIDS, maka perilaku remaja terhadap pencegahan HIV/AIDS tersebut menjadi baik. ${ }^{(27)}$

\section{Peran Tenaga Kesehatan terhadap Peran Teman Sebaya dalam pencegahan HIV/AIDS}

Hasil pengujian peran tenaga kesehatan terhadap teman sebaya dengan nilai $\mathrm{T}$ statistik sebesar 88,576546 > 1,96. Jadi, hasil penelitian ini ada pengaruh peran tenaga kesehatan terhadap teman sebaya. Maka, parameter peran tenaga kesehatan terhadap teman sebaya dikatakan signifikan.

Teman sebaya merupakan suatu kelompok remaja yang nilainya dianut oleh remaja lain yang berfungsi sebagai tempat bagi remaja berbagi dan sering perubahan prilaku remaja disebabkan oleh transfer perilaku terhapap sesama teman sebayanya. ${ }^{(28)}$

Hal ini sejalan dengan penelitian dimana hasil uji statistic Paired Sample T-Test didapatkan nilai $\mathrm{p}<0,0001<\alpha=0,05$ berarti Ho ditolak sehingga ada pengaruh kegiatan penyuluhan yang disampaikan oleh tenaga kesehatan dalam PKPR terhadap sikap remaja tentang perilaku pencegahan HIV/AIDS. ${ }^{(29)}$

Berdasarkan pembahasan di atas maka penulis berpendapat bahwa peran tenaga kesehatan dalam memberikan penyuluhan kepada teman sebaya disekolah akan 
memberikan tambahan pengetahuan kepada remaja, sehingga remaja lebih mengetahui bagaimana tentang prilaku pencegahan HIV/AIDS, sehingga perilaku remaja terhadap pencegahan HIV/AIDS tersebut menjadi baik.

\section{Peran Tenaga Kesehatan terhadap Pola Asuh Orang Tua dalam pencegahan HIV/AIDS}

Hasil pengujian peran tenaga kesehatan terhadap pola asuh orang tua didapat dengan nilai $T$ statistik sebesar $72,822150>1,96$. Dimana hasil penelitian ini ada pengaruh peran tenaga kesehatan terhadap pola asuh orang tua. Sehingga peran tenaga kesehatan terhadap pola asuh orang tua dikatakan signifikan.

Peran yaitu tingkah laku seseorang, kepercayaan, nilai, dan sikap yang diharapkan dapat menggambarkan perilaku yang seharusnya diperlihatkan oleh individu. Pola asuh memiliki definisi yaitu bagaimana orang tua bisa memperlakukan anaknya dengan baik, memberikan informasi dengan baik serta melindungi anak, hingga kepada upaya membentuk norma yang diharapkan oleh masyarakat pada umumnya. ${ }^{(25)}$

Hal ini sejalan dengan penelitian analisis terdapat hubungan kecenderungan peran tenaga kesehatan dan pola asuh orang tua dengan pencegahan perilaku seksual berisiko HIV/AIDS pada remaja dengan hubungan nilai $p$-value sebesar $0,008<0,05{ }^{(30)}$

Berdasarkan pembahasan di atas maka Penulis berpendapat bahwa peran tenaga kesehatan dalam memberikan penyuluhan disekolah akan memberikan tambahan pengetahuan kepada remaja, dan pola asuh yang diberikan orang tua kepada anaknya akan memberikan dukungan pada remaja tersebut sehingga remaja lebih mengetahui bagaimana perilaku pencegahan HIV/AIDS pada remaja tersebut.

\section{Pengaruh Peran Tenaga Kesehatan terhadap Persepsi dalam Pencegahan HIV/AIDS}

Hasil pengujian peran tenaga kesehatan terhadap persepsi mendapatkan nilai $\mathrm{T}$ statistik sebesar 114,889421 > 1,96. Dengan demikian hasil penelitian ini ada pengaruh peran tenaga kesehatan terhadap persepsi. Sehingga peran tenaga kesehatan terhadap persepsi dikatakan signifikan.

Persepsi adalah proses pengetahuan atau mengenali objek atau kejadian objektif dengan 149 bantuan indera, secara umum persepsi dianggap sebagai variabel yang mempengaruhi faktorfaktor perangsang, keadaan psikis, suasana hati dan faktor-faktor motivasional, suatu kejadian objektif ditentukan oleh kondisi perangsang dan faktor orgasme, dengan demikian persepsi antara seorang dengan orang yang lainnya akan berbeda karena setiap individu mengalami perbedaan situasi. ${ }^{(31)}$

Hal ini sejalan dengan hasil sesuai analisis kuantitatif koefisien korelasi rank spearman, dapat diketahui bahwa korelasi antara $\mathrm{X}$ dan $\mathrm{Y}$ dengan $\mathrm{N}=50$ diperoleh nilai sebesar 0,67 . Hasil analisis data menunjukkan bahwa pengaruh peran tenaga kesehatan dan persepsi memiliki hubungan positif yang mantap terhadap perilaku pencegahan HIV/AIDS. ${ }^{(32)}$

Berdasarkan pembahasan di atas maka Penulis berpendapat bahwa peran tenaga kesehatan dalam memberikan penyuluhan kepada disekolah akan memberikan tambahan pengetahuan kepada remaja, dan persepsi yang baik akan memberikan pendapat yang baik pada remaja tersebut sehingga remaja lebih mengetahui bagaimana perilaku pencegahan HIV/AIDS, sehingga perilaku remaja terhadap pencegahan HIV/AIDS tersebut menjadi baik.

\section{Pengaruh Sumber Informasi terhadap Peran Teman Sebaya dalam pencegahan HIV/AIDS}

Hasil pengujian sumber informasi terhadap peran teman sebaya dengan nilai $\mathrm{T}$ statistik sebesar 21,093038>1,96. Dengan demikian hasil penelitian ini ada pengaruh sumber informasi terhadap peran teman sebaya. Sehingga didapatkan nilai parameter dari sumber informasi terhadap peran teman sebaya dikatakan signifikan.

Remaja bisa menjaga system kekeluargaan, norma dan nilai-nilai tradisional yang ada telah mengalami pengikisan yang disebabkan oleh urbanisasi dan industrialisasi yang sangat cepat. Terdapat juga pengaruh teman sebaya melalui suguhan pornografi dan narkoba yang semakin mudah untuk diakses. Beberapa faktor yang mendorong remaja melakukan seks berisiko, diantaranya melalui pergaulan teman sebaya, faktor lingkungan dan keluarga yang mendukung perilaku tersebut, serta pengaruh perkembangan teknologi media massa. Terdapat banyak faktor yang menyebabkan remaja melakukan perilaku berisiko terinfeksi HIV dan AIDS seperti yang 
penelitian sebelumnya remaja memilih berada diluar rumah bersama dengan teman sebayanya sebagai kelompok, maka dapatlah dimengerti bahwa pengaruh teman sebaya pada pada perilaku lebih besar dari pada pengaruh keluarga. ${ }^{(33)}$

Hal ini sejalan dengan dimana paparan informasi menunjukan p-value 0.010, dan pengaruh teman sebaya $p$-value 0.858 terhadap pemanfaatan PIK-R. Multi variabel regresi logistic variable pengetahuan, sikap, perilaku terhadap PIK-R dapat memprediksi pemanfaatan PIK-R sebesar $18 \%{ }^{(9)}$

Berdasarkan pembahasan di atas maka penulis berpendapat bahwa sumber informasi dan dukungan teman sebaya yang baik akan memberikan perilaku yang baik pada remaja tersebut sehingga remaja lebih baik dalam berperilaku pencegahan HIV/AIDS.

Pengaruh Sumber Informasi terhadap Pola Asuh Orang Tua dalam pencegahan HIV/AIDS

Hasil pengujian sumber informasi terhadap pola asuh orang tua didapat dengan nilai $\mathrm{T}$ statistik sebesar 19,343954>1,96. Dengan demikian hasil penelitian ini ada pengaruh sumber informasi terhadap pola asuh orang tua Sehingga parameter sumber informasi terhadap pola asuh orang tua dikatakan signifikan.

Informasi dapat di artikan sebagai segala sesuatu yang dapat memberikan informasi pengetahuan dan wawasan seseorang atau banyak orang dan segala sesuatu berita atau informasi yang diperoleh seseorang untuk mendapatkan apa yang dia cari dan didapatkan dari segala arah. ${ }^{(34)}$

Media promosi kesehatan merupakan saluran (channel) yang digunakan untuk menyampaikan informasi kesehatan dan karena alat-alat tersebut digunakan untuk mempermudah penerimaan pesan-pesan kesehatan bagi masyarakat atau klien.(35)

Hal ini sejalan dengan penelitian dimana dari hasil uji regresi diketahui bahwa faktor dominan dalam penelitian ini adalah sumber informasi $(\mathrm{AOR}=2,58)$ dan pengaruh pola asuh orang tua sebesar AOR $=4,20) .{ }^{(10)}$

Berdasarkan pembahasan di atas maka Penulis berpendapat bahwa sumber informasi dan pola asuh orang tua dalam memberikan informasi kepada remaja tentang perilaku pencegahan HIV/AIDS, dan semakin baik sumber informasi yang diterima dan semakin

baik pola asuh orang tua terhadap anaknya maka semakin baik juga perilaku remaja dalam pencegahan HIV/AIDS.

\section{Pengaruh Sumber Informasi terhadap Persepsi dalam pencegahan HIV/AIDS}

Hasil pengujian sumber informasi terhadap persepsi didapat dengan nilai $\mathrm{T}$ statistik sebesar 30,118771 > 1,96. Dengan demikian hasil penelitian ini ada pengaruh sumber informasi terhadap persepsi. Sehingga parameter sumber informasi terhadap persepsi dikatakan signifikan.

Penyampaian suatu pesan atau informasi kesehatan dapat diperoleh melalui komunikasi dengan orang tua, komunikasi dengan tetangga maupun orang lain disekitar yang berasa di tempat tinggal, termasuk pula informasi dari petugas kesehatan. Sumber informasi langsung dari tenaga kesehatan adalah biasanya lebih akurat dan terpercaya informasinya, petugas kesehatan memberikan informasi biasanya dalam rangka konseling dengan pasien yang datang langsung ke pusat layanan kesehatan. ${ }^{(16)}$

Persepsi merupakan proses pengetahuan atau mengenali objek atau kejadian objektif dengan bantuan indera. Secara umum persepsi juga dianggap sebagai variabel yang dapat mempengaruhi berbagai macam faktor, seperti perangsang, cara belajar, keadaan psikis, suasana hati dan faktor-faktor motivasional, maka arti suatu objek atau suatu kejadian objektif ditentukan oleh kondisi perangsang dan faktor orgasme, dengan demikian persepsi antara seorang dengan orang yang lainnya akan berbeda. ${ }^{(36)}$

Hal ini sejalan dengan penelitian dimana hasil penelitian ada hubungan antara sumber informasi dengan persepsi dalam pencegahan HIV/AIDS pada siswa kelas X SMA Negeri 1 Jakarta dengan nilai $\mathrm{X}^{2}$ hitung sebesar 25.000 dan nilai signifikansi ( $p$ value) sebesar $0<$ $0,05 .^{(32)}$

Berdasarkan pembahasan di atas maka Penulis berpendapat bahwa sumber informasi dan persepsi dalam memberikan informasi kepada remaja tentang perilaku pencegahan 
HIV/AIDS dan semakin baik sumber informasi yang diterima dan semakin baik pendapat seseorang maka semakin baik juga perilaku remaja dalam pencegahan HIV/AIDS.

\section{Pengaruh Peran Teman Sebaya terhadap Pola Asuh Orang Tua dalam pencegahan HIV/AIDS}

Hasil pengujian peran teman sebaya terhadap pola asuh orang tua didapat dengan nilai $\mathrm{T}$ statistik sebesar 24,936551 > 1,96. Dengan demikian hasil penelitian ini ada pengaruh peran teman sebaya terhadap pola asuh orang tua Sehingga parameter peran teman sebaya terhadap pola asuh orang tua dikatakan signifikan.

Interaksi antar teman sebaya dapat memprediksi variabel perilaku penceghan HIV/AIDS dapat dipengaruhi oleh interaksi teman sebaya. Pendapat peran teman sebaya tidak mempengaruhi perilaku pencegahan HIV/AIDS oleh karena mahasiswa sudah memiliki pendapat sendiri dan dapat berargumen sesuai jalan fikirannya sehingga tidak dapat lagi tergantung pada kelompok teman sebaya serta sudah bisa bertanggung jawab terhadap dirinya sendiri dan termasuk segala bentuk perilaku yang ingin dilakukan. ${ }^{(37)}$

Hal ini sejalan dengan penelitian berdasarkan analisis data diperoleh hasil pola asuh orang tua dan kecerdasan emosi mempunyai pengaruh positif dan signifikan terhadap kecerdasan emosi. Pola asuh orang tua dan interaksi teman sebaya mempengaruhi kecerdasan emosi sebesar 37,9\%. Hal ini berarti jika pola asuh orang tuanya baik, maka akan diprediksi anaknya memiliki kecerdasan emosi, sesuai diajarkan oleh orang tuanya. Hal ini berarti semakin baik pola asuh orang tua dan interaksi teman sebaya semakin baik pula perilaku anak tersebut. ${ }^{(10)}$

Berdasarkan pembahasan di atas maka penulis berpendapat bahwa peran teman sebaya dan pola asuh orang tua dalam memberikan informasi kepada remaja tentang perilaku pencegahan HIV/AIDS, dan semakin baik teman sebaya semakin baik seseorang berperilaku dan maka semakin baik pola asuh orang tua terhadap anaknya maka semakin baik juga perilaku remaja dalam pencegahan HIV/AIDS.

Pengaruh Peran Teman Sebaya terhadap Persepsi dalam pencegahan HIV/AIDS
Hasil pengujian peran teman sebaya terhadap persepsi didapat dengan nilai $\mathrm{T}$ statistik sebesar 9,164425 > 1,96. Dengan demikian hasil penelitian ini ada pengaruh peran teman sebaya terhadap persepsi. Sehingga parameter peran teman sebaya terhadap persepsi dikatakan signifikan. Persepsi yaitu suatu siuasi dimana pengetahuan atau mengenali objek atau kejadian objektif dengan bantuan panca indera.

Pendapat tentang peran teman sebaya bisa mempengaruhi perilaku pencegahan HIV/AIDS dan bisa juga tidak dikarenakan mahasiswa sudah bisa menenukan pendapatnya sendiri dan dapat ber-argumen menggunakan fikirannya sendiri sehingga tidak dapat lagi tergantung pada kelompok teman sebaya serta sudah mulai dapat bertanggung jawab terhadap diri sendiri termasuk segala bentuk perilaku yang dilakukan. ${ }^{(38)}$

Hal ini sejalan dengan penelitian dimana brdasarkan perolehan tersebut dapat diambil kesimpulannya tentang persepsi yang penerimaan teman sebaya memiliki pengaruh terhadap penceghan HIV pada remaja di Jakarta. Dimana adanya sumbangan pengaruh persepsi penerimaan teman sebaya terhadap pencegahan HIV dengan melihat perolehan nilai Adjusted $\mathrm{R}$ Square. Nilai Adjusted $\mathrm{R}$ Square yang diperoleh pada penelitian ini sebesar 0.051 atau sebersar $5.1 \%$. Hal ini juga menunjukkan bahwa sisa nya sebesar $94.9 \%$ dipengaruhi oleh faktor lain selain dari penerimaan variabel teman sebaya, yaitu secara statistik nilai ini dapat memberikan penjelasan yaitu bahwa penceghan HIV dipengaruhi oleh persepsi penerimaan teman sebaya. ${ }^{(26)}$

Berdasarkan pembahasan di atas Penulis berpendapat bahwa peran teman sebaya berpengaruh pada persepsi seseorang, semakin baik peran teman sebaya memberikan informasi kepada remaja tentang perilaku pencegahan HIV/AIDS, semakin baik pula persepsi seseorang tersebut dalam berperilaku untuk pencegahan HIV/AIDS.

\section{Pengaruh pola asuh orang tua terhadap persepsi dalam pencegahan HIV/AIDS}

Hasil uji dari pola asuh orang tua terhadap persepsi dengan nilai $\mathrm{T}$ statistik sebesar $2,523110>1,96$. Berarti, hasil penelitian ini ada pengaruh pola asuh orang tua terhadap persepsi. Sehingga parameter pola asuh orang tua terhadap persepsi dikatakan signifikan. 
Pola pengasuhan merupakan cara atau pola yang diterapkan suatu keadaan atau situasi dalam kehidupan sehari-hari yang diterapkan terhadap anak, seperti mengasuh, membina, mengarahkan, membimbing, dan memimpin anak. Setiap asuhan orang tua memiliki caranya yang berbeda, terhadapa pengasuhan pada anaknya, tidak semua orang tua mengajrkan anaknya dengan sama, intinya orang tua dimanapun harus mengajarkan anaknya dan membimbing agar berperilaku baik, perbedaan seseorang dalam memberikan informasi yang ditangkap oleh panca inderanya disebabkan karena adanya faktor-faktor yang mempengaruhi proses pemaknaan tersebut, bisa dari faktor dari luar maupun faktor dari diri sendiri. ${ }^{(39)}$

Hal ini juga sejalan dengan penelitian yang dilakukan di Desa Sampang yang menunjukkan bahwa ada hubungan antara kontribusi fungsi keluarga dan persepsi dengan pencegahan penularan HIV AIDS pada kalangan remaja, dimana $\mathrm{p}=0,000$. $^{\text {(26) }}$

Berdasarkan pembahasan di atas maka Penulis berpendapat bahwa variabel dari pola asuh orang tua dalam memberikan informasi kepada remaja dimana tentang perilaku pencegahan HIV/AIDS, dan semakin baik asuhannya maka persepsi remaja semakin baik dalam berperilaku dan maka semakin baik pola asuh orang tua terhadap anaknya maka semakin baik juga perilaku remaja dalam pencegahan HIV/AIDS.

\section{Kesimpulan}

Dengan demikian, dari temuan tersebut dapat ditarik kesimpulan bahwa teman sebaya yang paling mempengaruhi perilaku remaja dalam pencegahan HIV/AIDS di SMK Tunas Bangsa Kabupaten Tangerang Tahun 2018, dikarenakan teman sebaya adalah tempat keseharian mereka dalam berinteraksi disekolah dimana teman sebaya berfungsi sebagai tempat bagi remaja berbagi dan sering perubahan perilaku remaja disebabkan transfer perilaku sesama teman sebaya. Model ini dapat memperlihatkan pengaruh antar variabel yang diteliti sebesar 32,563\%.

\section{Saran}

Berdasarkan hasil penelitian ini, disarankan agar orang tua dapat memberikan semangat baru dalam kegiatan yang diberikan atas prestasi anak remajanya dalam mewujudkan tujuan tertentu, yang dapat berupa pemberian hadiah, pujian dan penghargaan dan dijalinnya komunikasi yang baik antara anak remajanya dengan orang tua, terutama untuk anaknya dalam memilih teman dilingkungannya dan orang tua juga selalu menanyakan bagaimana pendapat dan perasaan anak bila mempunyai persoalan yang wajib dipecahkan.

\section{Daftar Pustaka}

1. Astutik. Definisi HIV/AIDS. Jakarta: Salemba medika; 2014.

2. Bertha S. HIV/AIDS. Jakarta: Widya Medika; 2012.

3. Dwi. Faktor-faktor yang Mempengaruhi Terjadinya HIV/AIDS pada Remaja. J Kebidanan ;2014.

4. Depkes RI. Profil Kesehatan Indonesia ; 2016. from: http://www.depkes.go.id

5. Kemenkes RI. Data Profil Kementrian Indonesia 2015 from: http://www.depkes.go.id

6. Inch X. HIV/AIDS Penyebab dan Penatalaksanaan. Jakarta: Widya Medika; 2012.

7. Ar.Topan. Perilaku Pencegahan HIV/AIDS pada Remaja. Din Kesehat. 2014;13.

8. Ar.Topan. Dinamika Kesehatan. Vo.13.No.13. Juli 2014 Perilaku Pencegahan HIV/AIDS Pada Remaja. 2014;13.

9. Haringi S. Gambaran Perilaku Siswa SMA dalam Upaya Pencegahan HIV/AIDS di Wiayah Kota Kendari. 2016;1-10.

10. Sari. Pengaruh Peran Keluarga, Sumber Informasi dengan Kejadian HIV/AIDS pada Remaja. J Keperawatan dan Kebidanan Stikes Dian Husada Mojokerto. 2015;22.

11.Mutisal. Pengaruh Kelompok Teman Sebaya terhadap Perilaku Konsumtif pada Remaja Puteri. Jurnail Ilm Kaji Gend. 2010;198.

12. Dinkes Banten. Profil Kesehatan Dinas Kesehatan Banten. 2015; Available from: http://www.dinkes.co.id

13.Notoadmodjo. Perilaku Kesehatan dan Ilmu Kesehatan. Jakarta: Rineka Cipta; 2013.

14.Asri NUR. Hubungan Peran Petugas Kesehatan Dan Media Diploma Iv Kebidanan Banda Aceh Tahun 2013. 2013;

15. Notoadmodjo. Promosi Kesehatan Dan Perilaku Kesehatan. jakarta; 2015.

16.Ditman. Sistem Informasi dan Komunikasi. Jakarta: EGC; 2009.

17.Subianto. Komunikasi, Politik, Media dan Demokrasi. Jakarta: Prenadamedia Group; 2013.

18. Setiadji. Hubungan Pengetahuan, Sikap dan Sumber Informasi dengan Upaya Pencegahan HIV/AIDS pada Remaja Komunitas Anak Jalanan di Banjarmasin. J Kebidanan. 2016;7.

19. Santrock. Peran Teman Sebaya terhadap Sesama Sebaya. Jakarta:EGC ; 2010 
20. Sujata. Pola Asuh Orang Tua dan Fungsi Orang Tua terhadap Keluarga. Jakarta: EGC; 2013.

21. Pavilianingtyas. Hubungan Pengetahuan HIV/AIDS dan pola asuh orang tua dengan sikap terhadap pencegahan penularan HIV/AIDS. Karya Ilm S1 Ilmu Keperawatan. 2015;0.

22. Jalaludin. Psikologi Persepsi dan desain persepsi. Jakarta: EGC; 2007.

23.Dian. Pengaruh Sumber Informasi, Persepsi dengan Kejadian HIV/AIDS. J Kebidanan Stikes Aisyiyah. 2013;1.

24. Cecep. Pelayanan Kesehatan Reprodukai Remaja. Jakarta : Rineka Cipta ; 2013

25. Peter. Peran dan pergaulan antar teman sebaya. 2005;

26. Aisyah. Pengaruh Peran Tenaga Kesehatan, Sumber Informasi, Persepsi dalam Pencegahan HIV/AIDS Universitas Indonesia. J Ilmu Kesehat. 2010;10-5.

27. Sardiman. Peran Tenaga Kesehatan dalam pencegahan HIV/AIDS. Peran Tenaga Kesehat dalam Pencegah HIV/AIDS. 2007;

28. Santosa. Kelompok Teman Sebaya. 2008;1-39.

29. Enggarwati. Faktor-faktor yang Berhubungan dengan Perilaku Seks Beresiko HIV/AIDS dan IMS pada Remaja. 2015;40-51.

30. Diah. Pengaruh Sumber Informasi, Pola Asuh Orang Tua terhadap Perilaku Pencegahan
HIV/AIDS. J Kebidanan Stikes Aisyiyah. 2013;18.

31. Waidi. Persepsi dalam setiap perilaku. Yogjakarta: Raja Grafindo; 2011.

32. Tuti. Hubungan Persepsi, Teman Sebaya terhadap Perilaku Pencegahan HIV/AIDS. J Kebidanan dan Keperewatan. 2017;13:19-24.

33. Hurlock. Remaja dan Permasalahanya. Jakarta: Raja Grafindo Persada; 2003.

34.Cangara H. Perencanaan dan Strategi Komunikasi. Jakarta: Raja Grafindo Persada; 2013.

35. Sutanto. Manfaat Sumber Informasi dan Fungsi Sumber Informasi. Jakarta: EGC ; 2003.

36. Slamento. Faktor-faktor yang mempengaruhi persepsi seseorang.Jakarta: EGC ; 2013.

37. Aryekti. Peran Teman Sebaya dalam Program Kesehatan Remaja. Yogjakarta: Graha Ilmu; 2009.

38. Slavin. Peran dan Interkasi teman sebaya. 2008;

39. Sujata. Pola asuh orang tua dan fungsi orang tua terhadap keluarga. 2013;

40.Sri N, Septiawan C. Pengaruh Sikap, Dukungan Teman Sesama Wanita Pekerja Seks (WPS) dan Motivasi terhadap Perilaku Pencegahan HIV/AIDS WPS. Jurnal Ilmiah Kebidanan Indonesia. 2019 Jul 16;9(02):66-78. 